\title{
Fund Management and Allocation of Funds for Rural Village: Challenges of Budget Preparation, Implementation and Reporting Accounting
}

\author{
Erna Hendrawati \\ Accounting Department, Faculty of Economics \\ University of Wijaya Kusuma Surabaya \\ Surabaya, Indonesia \\ ernauwks@gmail.com
}

\author{
Tantri Bararoh \\ Accounting Department, Faculty of Economics \\ University of Wijaya Kusuma Surabaya \\ Surabaya, Indonesia \\ tantribararoh@yahoo.co.id
}

\author{
Mira Pramudianti \\ Accounting Department, Faculty of Economics, \\ University of Wijaya Kusuma Surabaya \\ Surabaya, Indonesia \\ mirapramudianti@yahoo.com
}

\begin{abstract}
Indonesian government attempted to develop the villages. This was done through the Rural Development Movement Universe or abbreviated Movement Village. The purpose of this study was to explore the planning and development phases of the village and the funding allocation of village funds (DD) and the allocation of village funds (ADD) in the process of rural development and the obstacles and problems facing the village in Gresik. Data were collected from six villages as samples. Data were analyzed using the techniques of data reduction, data display, and verification. The results showed that all the villages as samples have been doing phase of the Rural Development Plan, Rural and Village APBD, RKPD according to applicable regulations. Implementation constraints RPJMD lack of participation of RT and RW to dig input from residents of the village and a period of 6 years to plan the program for too long. RKPD preparation Tlogobendung constraints, lack of active participation of $R T$ and $R W$ but in some other villages many proposals on the program of activities proposed by the RT, RW and other village institutions but eventually adapted to the indicative ceiling proposals received by the village. Lack of understanding of the village of rules related to planning, implementation and administration. Preparation of the 2017 budget year APBD delays plagued the indicative ceiling of funds received by the village. The use of village funds used for the rehabilitation and development of infrastructure of the village. Use of Funds Allocated village used to earning the village head, the device and allowances BPD.
\end{abstract}

Keyword-Village Fund (DD); Village Allocation Fund (ADD); RPJMD; RKPD; APBD

\section{INTRODUCTION}

The vision and mission of the government Joko WidodoJusuf Kalla is to prioritize the village fund to build a "village $3 \mathrm{~T}$ ", backward, isolated and remote villages with the launch of the universe rural development movement or movement abbreviated village. According to [1] rural development area is in development across the village in an attempt to speed up and improve the quality of care and empowerment of rural communities through a participatory approach implemented at per-determined specific areas defined by the mayor / district leader.

Preparation of the village should be considered in the implementation phases of development. Village burden much heavier than before in addition to providing services to rural communities. This is because the village was given the authority to manage large funds independently. Village fund began to be routed to the village in 2015, in 2017 the village had obtained three times the village fund distribution. Therefore, the ability of the village to manage the funds of this village is also not to be ignored. Therefore, the fraud that occurred in the financial statements of a program may be due to negligence or ignorance in the recording and bookkeeping.

On the one hand, it is undeniable is rarely the village has a good understanding of accounting as well as the education level of the village would affect the implementation of the planning, administration and reporting on the implementation of rural development using the village fund (DD) and the village fund allocation (ADD). This led to difficulties in preparing the village fund statements. Human Resources (HR) for the preparation of financial statements led to the financial reporting often encounter obstacles village. For that there needs to be training to be understood in a simple accounting by village. The training was light and not complicated, but it can ensure accountability and transparency in the management of village income. The basic understanding is important because if you did not understand errors will occur. The purpose of this study was to explore the 
planning stages of rural development and funding allocation of village funds (DD) and the allocation of village funds (ADD) in the process of rural development and the obstacles and problems facing the village in Gresik.

\section{METHODS}

The author uses qualitative research. Qualitative research is basically a research methods used to examine the condition of natural objects, where the researcher is a key instrument. Data collected by the method of triangulation, data analysis is inductive and qualitative research results more emphasis on the meaning of generalization [2].

Determining the sample based on probability sampling technique; This is because qualitative research see the sampling process as population dynamic parameters [3]. Selection of the sample using stratified sampling method through non proportionally, based on location. Two villages were selected from each district. The research location adjacent to Surabaya (Setro and Boteng village), Lamongan (ambeng-ambeng Watangrejo and Duduk Sampeyan village), and Gresik (Sidorukun and Tlogobendung village). The informant is a village and community agencies involved in the medium-term plan for rural development (rural development plan), village government work plan (RKPD) and rural income and expenditure village (APBD) in every village. The collection of data through participant observation, interviews and documentation.

After the data obtained from the field and collected the next step is to analyze the data. The data analysis technique based on [2]: data reduction, data display, and verification.

\section{RESULTS AND DISCUSSION}

\section{A. PHASE PREPARATION RPJMDesa}

From observations and interviews in six villages of Tlogobendung, Sidorukun, Boteng, Setro, Duduksampeyan and Ambeng-ambeng Watangrejo obtained phases planning rural development undertaken in the preparation RPJMD: Beginning of Pre Musrebang includes the formation of the drafting team RPJMDesa ; accommodate an appreciation of rural development in the form of (alignment of development policies of the district / city, the appreciation of the authority of the village which includes the identification and infentarisasi authority of the origin and scale of the village), the appreciation potential and village assets include natural resources (SDA), human resources (HR), physical , institutional, social, financial, spiritual, cultural, mapping appreciation village welfare; analysis of the results of the appreciation of rural development by field or program activities include: the village administration, rural development, rural community, rural community empowerment; RPJMD drafting a report containing the appreciation of development to the minutes, the data villages which have been harmonized, the data plan rural development program, the recapitulation of the proposed plan of village development activities.
Stages Musrebang includes: village development forum, which discussed the draft report RPJMD, the formulation of the policy of rural development which is derived from the vision, mission head of the village, a plan of priority areas, programs, activities organizing village administration (Pemdes), rural development, development of the village community, community empowerment village; draw up a draft improvement RPJMD to review the results and preparation based on the minutes of the meetings with establishment of villages 1; 2 village development forum to discuss and agree RPJMD.

Phase three is the Stipulation include: drafting team RPJMDesa finalizing documents and data RPJMDesa asset based welfare; The village head is drafting regulations on RPJMDesa village; discussion and agreement between the village head and BPD to establish village rural (Perdes) about RPJMD.

\section{B. RKPD STAGES}

Stages RKPD at the start of the Pre Musrebang starting from the head of the village formed a drafting team RKPDesa; appreciation of rural development to examine the indicative ceiling (plan for the village fund, the village fund allocation, tax sharing / retribution plan financial aid from the provincial and district), balance program or activity of the government, provinces, districts and the results of public aspirations, examine the RPJMD and RKPD (look at the scale of priorities proposed plan village activity for one budget year, evaluating the implementation RKPD previous year, the priority areas, program and budget of the village through the cooperation of the village and the third party, plan a program of activities, the village budget managed by the village as an authority assignment from the government, provincial and district; analyzing the results of the appreciation of rural development

Stages Musrebang include: rural development deliberation 1 to agree on the results of repeated scrutiny RPJMD document, form teams executing according to the type of activity and expertise required (consultation between village heads and community BPD); drafting RKPD based on the minutes of deliberation development 1 ; discuss and agree RKPD.

Stage Determination include: The drafting team RKPD improvement RKPD document; The village head is drafting regulations on RKPD village; Discussion and mutual agreement and BPD village heads to establish Perdes about RKPD.

\section{APBD STAGES}

Stages in preparing APBD: based RPJMD and prepare draft Regulation RKPD village (Raperdes) APBD; APBD Raperdes handed to the head of the village; Consultations village with BPD and the public; APBDesa Raperdes convey to the regent delegated to camat to be evaluated; If camat not provide results of the evaluation will be made to the determination of Perdes APBD; If the results of the evaluation of revisions, it will be improved; Otherwise, improvements will be made to the cancellation of village regulations APBD, 
revocation Perdes by village head and $\mathrm{BPD}$, using ceiling APBD previous year.

\section{Obstacles that Occurs when Preparing RPJM}

Constraints that occur during the preparation of RPJMD in Tlogobendung is the lack of participation of RT and RW to dig inputs citizens about what the development plan to be proposed to the village, the village mid-term plan (RPJMD) for six years is too long to design a program of what will be done. Boteng RPJMD constraint is the lack of awareness of the RT, RW to make a proposal RPJMD program, they handed over the village to describe the aspirations of its citizens. Finally, the village lays out proposals were conveyed orally every RT, RW in form proposals. Obstacles when drafting RPJMD Ambeng-ambeng Watangrejo is a period of 6 years to pour too long program plan for the village do not know how the development of social conditions and concerns about what is happening and what the program will do. Implementation RPJMD Setro and Duduk Sampeyan not experiencing technical problems in the field. RPJMDa Sidorukun, Setro, Boteng, Duduksampeyan and ambeng-ambeng Watangrejo display fields / type of activity, location, time estimates, goals / benefits, implementation time, cost estimates and implementation patterns, while RPJMD Tlogobendung only RPJMD Tlogobendung matrix display revision.

\section{E. Problems that Occurred while Preparing RKPD}

Constraints that occur during the preparation of RKPD tlogobendung is less active participation of RT and RW to deliver role in discussion of the draft proposal RKPD, lack of understanding of the rules related to planning, implementation and administration of that village have to learn to define rulesrules in its implementation. Sidorukun village obstacles that happen is the RT, RW does not hold deliberations among residents in the neighborhood to dig up the aspirations of its citizens, the early stages of the distribution of funds and lack of socialization village on the use and reporting of village funds. Constraints in the village Boteng, the lack of readiness of the village in terms of planning and administration of the use of village funds obtained funding starting in 2015. Constraints in the village ambeng-ambeng Watangrejo number of the proposed program of activities proposed by the RT, RW and other village institutions but in the end the proposal planned activities tailored to the fund that exist in the village received the indicative ceiling. RKPD implementation of fiscal year 2017 in the village of Sit sampeyan Setro and running smoothly.

\section{F. $\quad$ Sources and Use of Funds in APBDESA 2017}

Sources of funding in APBDesa Tlogobendung, Sidorukun, Boteng, Setro, Duduk Sampeyan and Ambengambeng Watangrejo fiscal year 2017 was obtained from the village fund at least $50 \%$, and a minimum of $20 \%$ of the village fund allocation. Of funding village funds used for the construction or rehabilitation of infrastructures, Gapuro villages, roads, shafts village and road infrastructure, roads, infrastructure environmental sanitation village (management sewage, drainage, toilet facilities), for development activities sports hall raga. Village fund allocation (ADD) is used for the village head and the income of at least $50 \%$ and at least $16 \%$ of BPD benefits of ADD received funding.

The village planning is prepared based on the agreement in the village meeting (musdes) [4]. The implementation of the Rural Development Meeting (RPJM) is made after the elected village head is established so that the RPJM can be ratified in the form of Perda at least three months after the village head is inaugurated. Permendagri No. 114 of 2014 on rural development, stages of preparation of RPJM. a) Village Head form a team of RPJM. The team consists of the village head as the builder, the village secretary as the chairman, the head of the community empowerment institution as secretary, the member comes from the village apparatus, the community element. Number of teams at least 7 people, maximum 11 people and obliged to include women. The drafting team is determined by a Village Head Decree. b) Aligning the policy directions of city development planning to integrate district development programs and activities with village development. By recording and sorting the program plans and development activities of districts / municipalities into the village, then grouped into areas of administration of village government,village development, village community development and empowerment of village communities. c) Assessment of village conditions: aligning village data in the form of natural resources, human resources and development resources; comparison of village with current conditions. d) Preparation of village development plans through Musdes, excavation of community ideas, knowing potentials, opportunities and problems faced by villages through village meetings or special deliberations of village communities. e) Preparation of draft RPJMDesa f) The draft RPJM is approved by the Village Head g) Musrenbang RPJM h) Improvement of RPJM from village Musrenbang i) Determination of RPJM to Perdes

The Village Expenditure Budget (APBDesa) shall be prepared in accordance with the RPJMDesa and RKPDesa. APBDesa consists of the income, expenditure, and financing of the Village. Budget components according to [5].

\section{CONCLUSION}

Tlogobendung village, Sidorukun, Boteng, Setro, Duduk Sampeyan and Ambeng-ambeng Watangrejo in the phase of rural development plan, RKPD and APBD already by the rules. Implementation constraints RPJMD lack of participation of RT and RW to dig input from residents of the village and a period of 6 years to plan the program for too long. RKPD preparation Tlogobendung constraints, lack of active participation of RT and RW but in some other villages many proposals on the program of activities proposed by the RT, RW and other village institutions but eventually adapted to the indicative ceiling proposals received by the village. Lack of understanding of the village of rules related to planning, implementation and administration. Preparation of the 2017 budget year APBD delays plagued the indicative 
ceiling of funds received by the village. The funding source village budget year 2017 was obtained from the village fund a minimum of $50 \%$ and $20 \%$ of the allocation of village funds. Use of the village fund (DD) is used for the rehabilitation and development of infrastructure of the village. Use of the village fund allocation widely used for village head and the income and benefits BPD.

Suggestions based on research findings and conclusions can be stated below. The need for dissemination of the rules related to the conduct of the planning, implementation and accountability of the use of funds. Needed assistance and monitoring of the implementation of rural development. Development of mental abilities and village in the implementation stages of planning, implementation and accountability. Absence of information to the public about the existence of village funds received by the village and what programs will be planned.

\section{ACKNOWLEDGEMENT}

Thanks to Universitas Muhammadiyah Sidoarjo.

\section{REFERENCES}

[1] UU No.6 Tahun 2014 TENTANG DESA

[2] Sugiono. 2015. Metode Penelitian Pendidikan (Pendekatan Kuantitatif, Kualitati Dan R \& D), Penerbit Alfabeta. Bandung

[3] Satori Djam'an Dan Komariah Aan. 2014. Metode penelitan Kualitatif. Penerbit Alpabeta. Bandung

[4] Permendagri Nomor 114 Tahun 2014 TENTANG Pedoman Pembangunan Desa

[5] Permendagri No. 113 Tahun 2014 